\title{
OBITUARY
}

\section{Prof. H. A. Kluge}

News has only recently been received of the death of Prof. Hermann A. Kluge on December 25, 1956. We are much indebted to Mrs. Helen Androsova, of the Zoological Institute, Leningrad, who has supplied the biographical details for this notice.

Kluge was born in Radom, Poland, in 1871, and graduated in 1896 at the University of Kazan, taking his master's degree and becoming Privatdocent there in 1899. He had already gained the gold medal of the University for his first research investigation (on the natural history of the freshwater Polyzoa), and had studied in 1897 at the Solovetski Biological Station on the White Sea. His major scientific interests for the rest of his life, the Arctic and the Polyzoa, were thus established. Between 1900 and 1907, in preparation for his doctor's degree, Kluge studied at the Zoological Station at Naples, and also at museums in Germany, Sweden, Denmark and England, where he paid particular attention to the collections of Polyzoz from the various oceans.

Returning to Russia, Kluge began to work on the previously unstudied collections of Polyzoa from Russian seas in the Zoological Museum (now Institute) of the Academy of Science at Leningrad. He con. tinued this work throughout his life, and the resulting series of papers demonstrated the existence in Russian Arctic waters of some 350 species of Polyzoa, many of them new. Two important contributions, on which he had worked for many years, are to be issued posthumously. Kluge's investigations also extended to the Polyzos of West Greenland and the Antarctic. The care and accuracy of his descriptions and fine drawings, which are typical of all his work, are well seen in his monograph (1915) of the Anascan Polyzor of the Deutsche Südpolar Expedition of 1901-3, perhaps the best known of all his publications to European workers. He also wrote on such littlestudied groups as the Kamptozoa, Rhabdopleura and the cirripede Dendrogaster.

But all this was only part of Kluge's scientific life. From 1908 until 1933 he was director of the Murman Biological Station in Kola Bay, where he remained as a scientific worker after his retirement. Though not a large institution, it has been described as a model of its kind, with an excellent aquarium, a good library and museum, and well equipped for marine biological investigations. In 1934 Kluge visited the north of Novaya Zemlya, where he spent the winter at the polar station at Cape Zhelaniya. He was also one of the founders of the Arctic Museum in Leningrad, of which he was director for $\operatorname{som} \theta \operatorname{time}$.

Kluge devoted his life and energy to the study of the zoology of the austere far north. Our knowledge of the biology of the Arctic Ocean owes much to him.

AnNa B. Hastings

H. Dighton Thomas

\section{NEWS and VIEWS}

Sir James Swinburne, Bart., F.R.S.

Str JAMES SwINBURNe celebrated his hundredth birthday on February 28. Sir James, who until 1953 was chairman of Bakelite, Ltd., and who is now honorary president of the Company, is a distinguished engineer and one of the world's pioneers in the field of synthetic resins. His original work on phenolic resins at the beginning of the century made a major contribution to the development of the modern plastics industry. During his long life Sir James Swinburne has had many interests. In addition to being a Fellow of the Royal Society, he is past president of the Institution of Electrical Engineers, a past president of the Faraday Society, and a member of the Institution of Civil Engineers. $\mathrm{He}$ has always been interested in sociology and among his publications is the work "Population and the Social Problem". He has also been keenly devoted to music, and one of his early interests was the electric organ. Another of his hobbies is horology, and he has published books and papers on this subject. Sir James has now retired from active occupations to Bournemouth.

\section{Social and Preventive Medicine at Belfast :}

Prof. A. C. Stevenson

Prof. A. C. Stevenson, herd of the Department of Social and Preventive Medicine in The Queen's University, Belfast, will vacate his chair on April 1 to take up a new appointment as director of a Medical Research Council Population Genetios Unit. Prof. Stevenson joined the Department in 1948, after holding the post of senior lecturer in public heelth at the London School of Hygiene and Tropical Medicine. Prof. Stevenson has taken an active interest in the affairs of the Institute of Clinical Science, in which his Department is housed, which has given him ample opportunities for research in the field of genetics. Fortunate in having a defined population of convenient size for study in Northern Ireland, he has made a detailed study of the distribution of several harmful genes, including those involved in the transmission of myoclonic epilepsy, muscular dystrophies, congenital malformations, achondroplasia, epiloia, rheumatic fever, deaf mutism, retinoblastoma and tylosis palmaris et plantaris. Prof. Stevenson is the author of "Recent Advances in Social Medicine", published in 1950 by Churehill (London). In 1953 he was one of a team of medical scientists which visited Indonesia to study the public health problems and needs of that country for the World Health Organization.

The increasing hazards from ionizing radiation have directed attention to the fact that we have very few data on the genetic effects of radiation on human beings. Further information is required on the genetic structure of human populations and there is an urgent need for the collection of more information on fertility, consanguinity and mortality. The formation of a Medical Research Council Unit for the study of population genetics is a step in the right direction, and Prof. Stevenson's experience in Northern Ireland should stand him in good stead as head of the new Department. 